\title{
Implementation of waste banks for reduction of solid waste in South Surabaya
}

\author{
Warmadewanthi $^{1^{*}}$ and Millati Haqq ${ }^{1}$ \\ ${ }^{1}$ Department of Environmental Engineering, Institut Teknologi Sepuluh Nopember, Surabaya, \\ Indonesia
}

\begin{abstract}
Surabaya has become one of the cities in Indonesia with the largest volume of solid waste. One way to reduce waste generation in Surabaya City is through waste banks. The number of waste banks in Surabaya is 374 units since 2012 , with 0.55 ton/day or a $0.05 \%$ reduction effort against total waste. The non-organic municipal waste potential that can be utilized is $40 \%$ and the total waste reduction for non-organic waste is $0.13 \%$. The unit price of each type of solid waste is one of the main factors in people's willingness to sell their solid waste. The higher the price of the waste, the more revenue they will earn. This research is focused in South Surabaya where the greatest number of waste banks is located. Based on typical mass balance analysis, the total waste that can be reduced is $20 \%$ for compostable waste and $18.24 \%$ for non-compostable waste. Meanwhile, based on research, the total waste is reduced by $10.16 \%$ for compostable waste and only $0.343 \%$ for non-compostable waste. The reduction potential occurring through the waste bank activities is $0.146 \%$ of the total generation of $237,801.9 \mathrm{~kg} /$ day. The reduction percentage needs to be increased so that the volume of municipal waste can be suppressed. Therefore, there must be an effort to improve the performance of waste banks or to increase the number of waste bank units.
\end{abstract}

\section{Introduction}

The population of Surabaya City is increasing from year to year, and directly proportional to the amount of solid waste generated. In 2014 the population of Surabaya was recorded at $2,853,661$ inhabitants, whereas in 2015 it was 2,943,528 inhabitants [1]. The increase of population has caused the solid waste in the city to increase. Surabaya City has become one of the cities in Indonesia with the largest volume of solid waste [2]. The volume of solid waste production in the city in the second quarter of 2016 was $9,593.71 \mathrm{~m}^{3} /$ day, and the amount of solid waste handled in the landfill was $5,236.67 \mathrm{~m}^{3} /$ day or $55 \%$ [3]. This is classified as the main problem because the land area of the Benowo Landfill is not well equipped to handle the entire solid waste of Surabaya City, so the potential for pollution is large, and solid waste is the second factor contributing to greenhouse gas emissions in Surabaya, and could, therefore, affect other aspects of environmental health. There are 374

\footnotetext{
*Corresponding author: warmaputu@gmail.com
} 
waste bank units in Surabaya recorded since 2012, although not all are active. Therefore, there should be an improvement in their performance, or some alternative is needed.

As an alternative solution to overcome the problem of solid waste in urban areas, the waste bank is a social engineering activity [4] that teaches people to sort out their solid waste and to raise public awareness of solid waste treatment activity. Waste banks have various activities supported by the $3 \mathrm{R}$ concept. A waste bank is a concept of the dry waste collection that has been sorted and has management like a conventional bank, but the savings are not financial but solid waste. The saved waste will be weighed and rewarded with some money, then sold to industries that are already working with the waste banks or the collectors. For example, plastic packaging could be purchased by local administrators to be recycled into handicraft items. A waste bank is a place for sorting and collecting recycled or reused solid waste which has some economic value [5]. Waste banks as an environmental management program that were designed by the city Government to reduce the volume of solid waste in Surabaya with community participation [6]. The local government has reduced the solid waste from waste banks to 0.55 tons/day [3].

However, the problem faced today is that it is not yet known what amount of total solid waste is produced, the amount of solid waste deposited in waste banks, the final flow of solid waste that occurs in waste banks, and the actual reduction in each waste bank of municipal solid waste. Therefore, the method used in this research is material flow analysis. This method has the potential to predict the flow of waste composition [7]. This study analyses the material flow at the city scale using a method for examining the given system by calculating all its material inputs, the accumulation of material and its results within the system boundary [8]. Using the material flow analysis method, we will identify the material flow of solid waste generated from waste banks in Surabaya City; therefore the reduction of municipal solid waste that occurs in these waste banks can be determined with certainty.

\section{Methodology}

\subsection{Determination of research area}

The total number of waste banks located in Surabaya City is 374 units spread across several districts since 2012. However, after the preliminary survey, only 266 active waste bank units in Surabaya are available. The determination of the research area is based on the number of active waste bank units and the number of people in a region. In South Surabaya, there is the largest number of waste banks, and this is the most populous area, so the research area is selected as the southern part of Surabaya, with a total of 63 waste banks. The locations of the waste banks in South Surabaya are presented in Fig. 1.

Determination of the proportional random sampling area is based on population density. Based on calculations, the population density based on the classification is presented in Table 1.

The stratified random sampling method is used to determine the sampling area of waste generation by random selection, and the data obtained are as follows: 1) High density population: Sawahan sub-district; 2) Medium density population: Wonokromo sub-district; 3) Low density population: Gayungan and Jambangan sub-district.

Based on SNI 19-3964-1994, the sampling in this study will use as many as 100 samples. Thus, the number of households taken per sub-district is determined by the percentage ratio of the population density shown in Table 2 . 


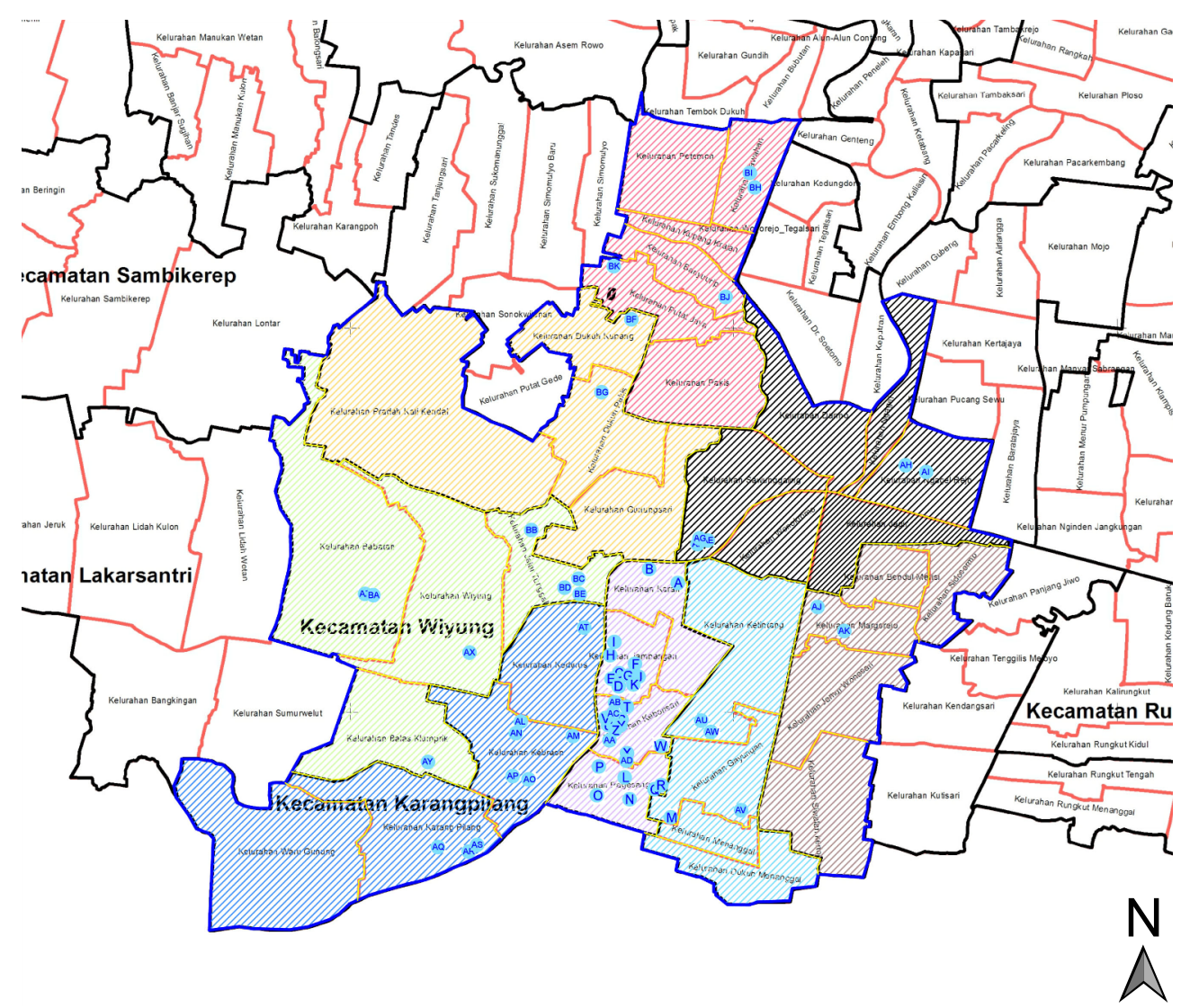

Fig. 1. Locations of waste banks in South Surabaya.

Table 1. Classification of population density of South Surabaya.

\begin{tabular}{|c|c|c|c|}
\hline Sub-district & $\begin{array}{c}\text { Total population } \\
\text { (person) }\end{array}$ & $\begin{array}{c}\text { Population density } \\
\text { (person/km² }\end{array}$ & Information \\
\hline Sawahan & 211.748 & 30.555 & High \\
\hline Wonokromo & 167.212 & 19.742 & Medium \\
\hline Karangpilang & 74.093 & 8.027 & Low \\
\hline Dukuh Pakis & 61.500 & 6.187 & Low \\
\hline Wiyung & 70.151 & 5.630 & Low \\
\hline Wonocolo & 82.387 & 12.169 & Low \\
\hline Gayungan & 46.451 & 7.653 & Low \\
\hline Jambangan & 50.789 & 12.122 & Low \\
\hline
\end{tabular}


Table 2. Total household respondent sampling.

\begin{tabular}{|c|c|c|c|c|}
\hline Sub-district & $\begin{array}{c}\text { Total population } \\
\text { (person) }\end{array}$ & Information & \% density & $\begin{array}{c}\text { Total households } \\
\text { to be sampled }\end{array}$ \\
\hline Sawahan & 211.748 & High & $44 \%$ & 44 \\
\hline Wonokromo & 167.212 & Medium & $35 \%$ & 35 \\
\hline Gayungan & 46.451 & Low & $11 \%$ & 11 \\
\hline Jambangan & 50.789 & Low & $10 \%$ & 10 \\
\hline Total & 476.200 & & $100 \%$ & 100 \\
\hline
\end{tabular}

\subsection{Household solid waste generation and composition}

The technical aspects consist of waste generation and waste composition in the waste bank. The waste generation measured is the waste generation in the source. The generation analysis was conducted for eight consecutive days [9], and the results were used to find out the amount of household waste that is produced and collected for the waste bank so that the amount of the reduction can be known.

Based on the results of the calculation of waste generation, the next analysis is of the waste composition, conducted as much as three times over eight days. The waste composition in waste banks includes plastic waste, paper waste, metal waste, glass waste, cloth waste, rubber waste, and others. The paper waste comprises HVS paper, newspapers, and cardboard. The metal waste includes cans, aluminum, iron, etc. The results of the analysis of the waste generation and composition will be used to find out the potential waste reduction at source through the waste banks. The number of waste bank customers will be investigated directly through interviews with waste bank management.

\subsection{Mass balance analysis}

In this analysis, a field survey is required directly. The way to get the mass balance analysis is by knowing the flow of waste generation along with the waste composition at the source, in waste banks, taken by collectors, until the final flow is determined by the collector or by the associated industries. Thus, the mass balance that occurs in the waste bank and the amount of waste reduction can be identified.

\section{Results and discussion}

\subsection{Household solid waste generation and composition}

The amount of waste generated in several districts in South Surabaya varies. The number of residents in the household and the current population of Surabaya City greatly affect the waste generated. The existence of reduction activities affect the current waste generation, such as the use of waste bank activities, composting, and other 3R activities.

South Surabaya is a medium density area where the waste generation value is considered as $0.7-0.8 \mathrm{~kg} /$ person/day [10]. The result of the measurement of household waste in South Surabaya is $0.31 \mathrm{~kg} /$ person/day from the total sample of 100 households. The rate of waste generation obtained is thus different from the SNI, because the sampling 
in this study was done for every home in several districts in South Surabaya. The rate of waste generation in this study is not very different from other research related to household waste management in Surabaya. The rate of waste generation in Wonokromo sub-district is $0.224 \mathrm{~kg} /$ person/day [11] in Gubeng sub-district is $0.32 \mathrm{~kg} /$ person/day, while Sukomanunggal sub-district has an average solid waste generation rate of 0.27 $\mathrm{kg} / \mathrm{person} /$ day [12]. The change of generation is influenced not only by the population but also by the pattern of life and population mobility.

The composition is examined by sorting the waste based on types, such as waste food, plastic, paper, rubber, iron/metal, cloth, glass, hazardous items, and others. The result of the measurement of household waste composition in South Surabaya is shown in Fig. 2.

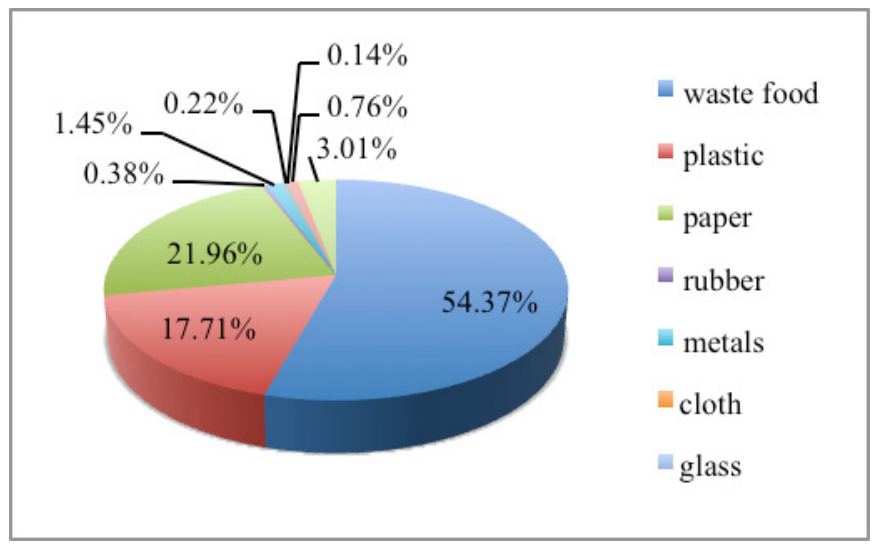

Fig. 2. Total waste composition in South Surabaya.

Based on the diagram, it is seen that food waste accounts for the largest percentage of $54.37 \%$ and the dry waste that dominates the waste composition in South Surabaya is paper waste, with a percentage of $21.96 \%$. Other solid waste contained in household waste includes diapers.

\subsection{Solid waste generation in waste banks}

The surveyed waste banks weighed the solid waste collected from the customers. Weighing is generally done once a month, and then the collector comes to pick up the solid waste to resell it to the relevant industries. The solid waste classification in every waste bank is different, depending on the collector of the waste bank. The data on the average annual waste weighed at the surveyed waste banks are presented in Table 3.

It is found that the biggest generation is at the Hidup Sejahtera waste bank. This is because the customers of the waste bank in Hidup Sejahtera are very enthusiastic about collecting waste. The average data on the monthly waste generation and total customers of each of the studied waste banks are presented in Table 4.

Based on the number of customers and the average generation, it is found that the waste banks at GKS and Hidup Sejahtera are examples of active waste banks, while Mekar Asri and Sejahtera are examples of inactive waste banks. The numbers of customers at Mekar Asri and GKS do not differ much, i.e., 44 people and 45 people, but the average of the resulting generation is very different. Based on field observations, the residents of Mekar Asri and Sejahtera are not saving very actively. 
Table 3. Data on average annual waste weight at surveyed waste banks in South Surabaya.

\begin{tabular}{|c|c|c|c|}
\hline \multirow{2}{*}{ Name of waste bank } & \multicolumn{3}{|c|}{ Waste generation (kg/month) } \\
\cline { 2 - 4 } & $\mathbf{2 0 1 6}$ & $\mathbf{2 0 1 7}$ & $\mathbf{2 0 1 8}$ \\
\hline GKS & - & 305.62 & 326.61 \\
\hline Guyub Sayekti & 177.08 & 165.29 & 181.08 \\
\hline Melati & - & 132.80 & 115.13 \\
\hline Mekar Asri & - & 75.69 & 41.25 \\
\hline Mulyorejo & 284.606 & 226.16 & 197.37 \\
\hline Hidup Sejahtera & 524.90 & 412.02 & 355.88 \\
\hline Mekar Jaya & - & 123.49 & 56.83 \\
\hline Lidah Buaya & - & 134.17 & 106.92 \\
\hline Sejahtera & 78.87 & 53.77 & - \\
\hline
\end{tabular}

Table 4. Summary of average waste generation in waste banks.

\begin{tabular}{|c|c|c|}
\hline Name of waste bank & Ave. waste generation (kg/month) & Total customers \\
\hline GKS & 326.61 & 45 \\
\hline Melati & 115.13 & 15 \\
\hline Mekar Asri & 41.25 & 44 \\
\hline Guyub Sayekti & 181.08 & 50 \\
\hline Mulyorejo & 197.37 & 50 \\
\hline Hidup Sejahtera & 355.88 & 43 \\
\hline Lidah Buaya & 106.92 & 27 \\
\hline Sejahtera & - & 60 \\
\hline Mekar Jaya & 56.83 & 22 \\
\hline
\end{tabular}

\subsection{Mass balance analysis}

The mass balance of waste was obtained from the survey of waste measurements conducted with the respondents and the waste banks. Based on nine surveyed waste banks, the data were generalized as the total for waste banks in South Surabaya. According to the generalized data, the potential waste reduction in South Surabaya through waste banks is only $349 \mathrm{~kg} / \mathrm{day}$. Compared with the total waste generation, the waste banks could reduce by $0.146 \%$ of the total waste generation in South Surabaya. Based on the non- compostable waste (dry waste) results, waste banks could reduce this dry waste by $0.343 \%$. Also, almost 
all the customers of the waste bank contribute to the composting activities, giving a reduction in this source of waste that is equal to $10.16 \%$.

A study conducted in one of the sub-districts in South Surabaya, Wonokromo, concluded that the largest reduction was carried out in the transfer depo by the scavengers at $972.57 \mathrm{~kg} /$ day or $16 \%$ of the total dry waste generation of $6,133.68 \mathrm{~kg} /$ day. The reduction from the waste bank in Wonokromo sub-district is only $49.49 \mathrm{~kg} / \mathrm{day}$ [11]. This shows an increase in waste reduction through the waste bank activities when compared to previous research, which was just in one sub-district in South Surabaya. Fig. 3 shows the mass balance of total waste in the area of South Surabaya.

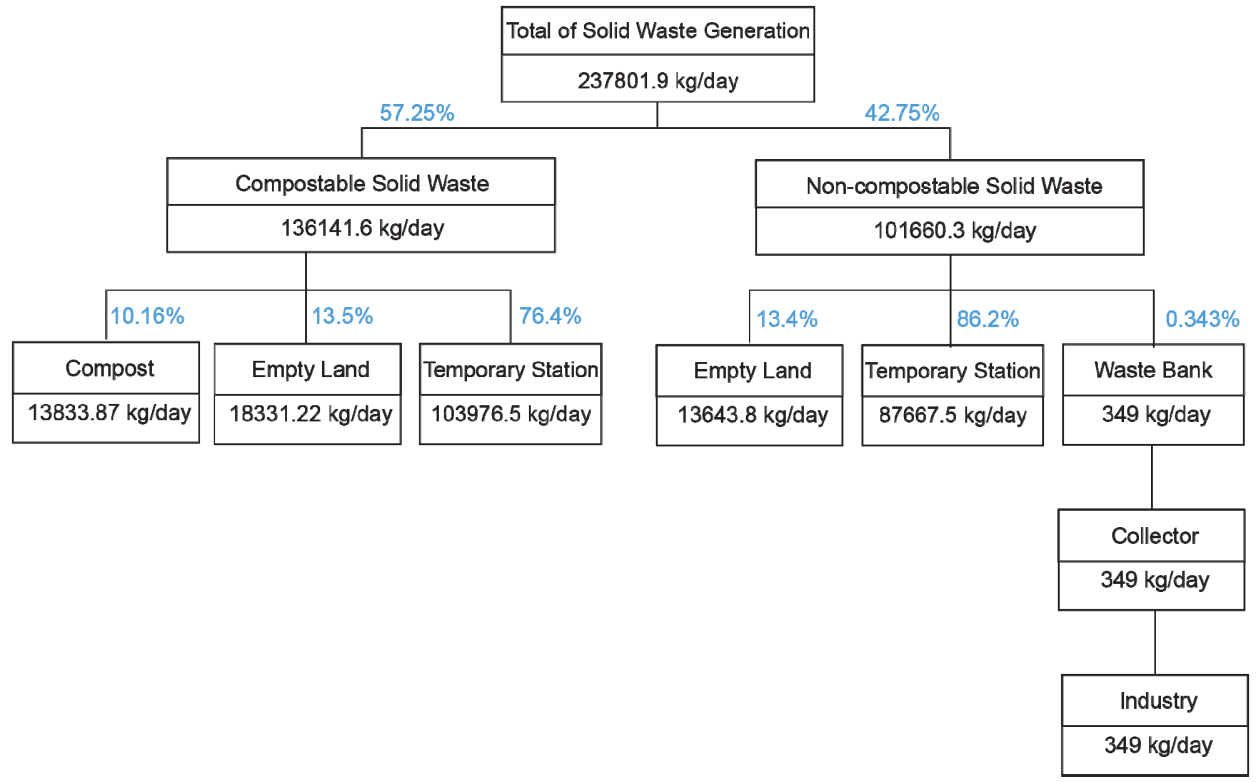

Fig. 3. Mass balance of existing total waste in South Surabaya.

Table 5. Percentage of recovery factor in South Surabaya.

\begin{tabular}{|c|c|c|c|}
\hline Type of Waste & \% RF existing & \% RF* & Difference (\%) \\
\hline Compostable & 10.16 & 80 & 69.84 \\
\hline Plastic & 0.05 & 50 & 49.9 \\
\hline Paper & 0.07 & 40 & 39.9 \\
\hline Rubber & 0.18 & & \\
\hline Metals & 0.11 & 80 & 79.89 \\
\hline Cloth & 0.01 & & \\
\hline Glass & 0.42 & 70 & 69.6 \\
\hline Others & 0.01 & & \\
\hline
\end{tabular}

Note:*: \% typical recovery factor $[13,14]$ 
Referring to the ideal waste composition and recovery factor [13, 14], the potential reduction in South Surabaya region could be improved. Table 5 shows the type of waste and the percentage of the current recovery factor and the ideal recovery factor to determine how much the reduction can be increased by using the waste banks in South Surabaya area.

According to Table 5, the ideal mass balance is obtained as in Fig. 4.

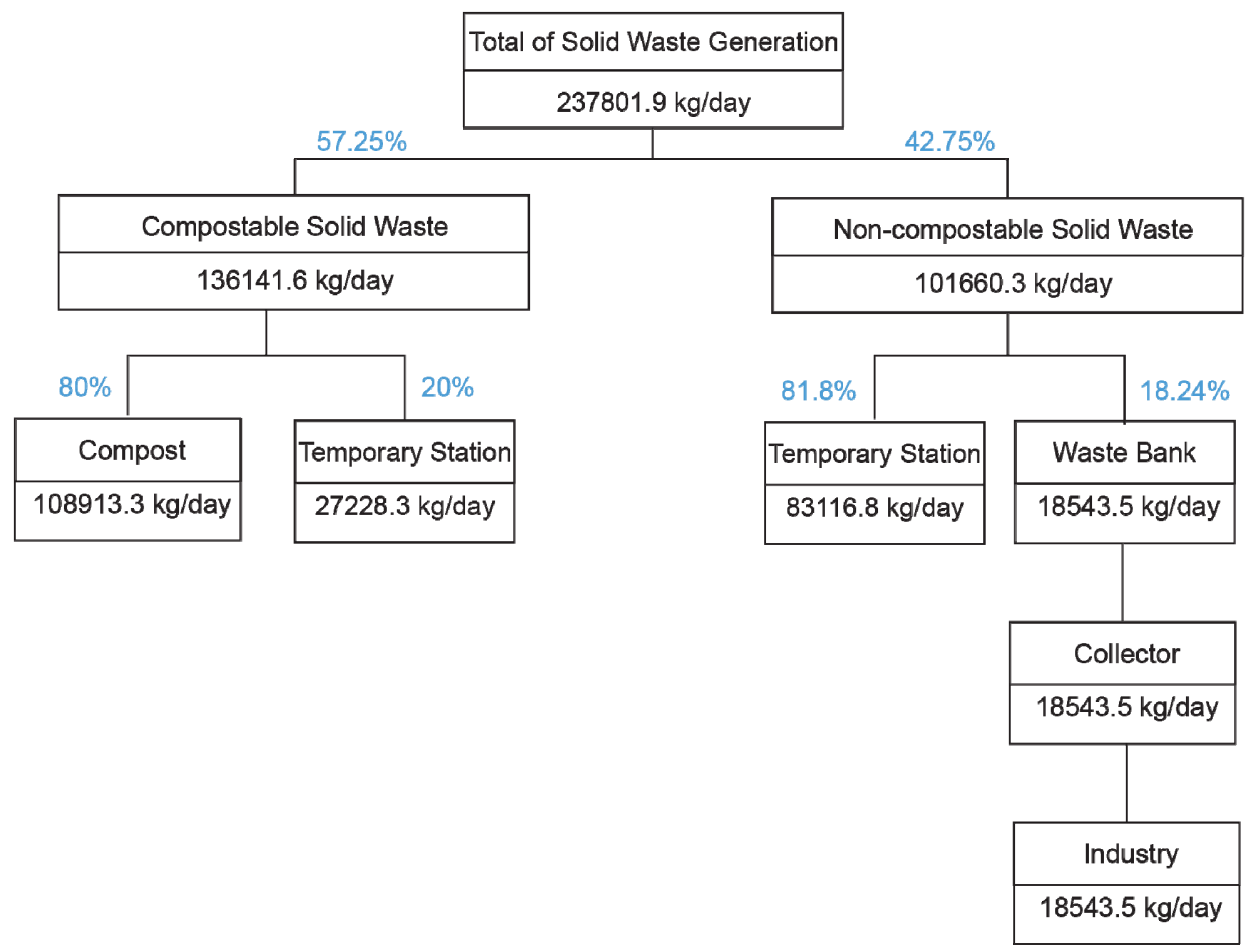

Fig. 4. Theoretical mass balance.

Based on the theoretical mass balance, the potential solid waste that should be managed by the waste bank is $18.2 \%$ of the total dry waste. Also, waste bank customers could contribute more to increase the amount of waste that can be composted. The potential reduction needs to be supported by increasing the number of customers and the performance of the waste banks, as well as reduction efforts, mainly to reduce the amount of waste to be composted from the source of waste. There are various solutions to improve the performance of waste banks, one of which involves a need for land to enable the customers to store waste for one month or following the weighing schedule. This would increase public interest in making use of waste banks.

\section{Conclusions}

The total solid waste generation in South Surabaya is $237801.9 \mathrm{~kg} /$ day, which consists of $57.25 \%$ compostable waste and $42.75 \%$ non-compostable waste (dry waste). The total number of active waste banks in South Surabaya is 63 units, with a total of as many as 11,240 customers. Waste banks in South Surabaya can reduce by $0.146 \%$ of the total waste generation or $0.343 \%$ of non-compostable waste (dry waste). The potential waste reduction that should be managed by waste banks is $18.2 \%$ of the total non-compostable waste (dry waste). 


\section{References}

1. Central Bureau of Statistics Surabaya, Surabaya city in figures 2017 (BPS Kota Surabaya, Surabaya, 2017)

2. Indonesian Central Bureau of Statistics, Statistik lingkungan hidup Indonesia 2016 (2016)

3. Sanitary and Green Open Space Agency. Informasi kinerja pengelolaan lingkungan hidup daerah tahun 2016 (Dinas Lingkungan Hidup Kota Surabaya, Surabaya 2016)

4. R.J. Ridley-Duff, M. Bull, Understanding social enterprise: theory and practice (Sage, London, 2011)

5. Minister of the Environment. Peraturan Menteri Negara Lingkungan Hidup RI No.13 Tahun 2012 tentang Pedoman Pengelolaan Reduce, Reuse dan Recycle Melalui Bank Sampah (2012)

6. S. Muntazah, Pengelolaan program bank sampah sebagai upaya pemberdayaan masyarakat di bank sampah bintang mangrove Kelurahan Gunung Anyar Tambak Kecamatan Gunung Anyar Surabaya (2015)

7. $\quad$ P.H. Brunner, W.R. Ernst, Waste Man. \& Res. 4 (1986)

8. F.A. Shafie, D. Omar, S. Karuppannan, N. Shariffuddin. Proc. Social and Behavioral Sciences, 234 (2016)

9. National Standardization Agency. Method of Taking and Measuring Sample of Generation and Composition of Municipal Waste SNI 19-3964-1994 (1994)

10. National Standardization Agency. Specification of Waste Generation for Small Town and Medium City SNI 19-3983-1995 (1995)

11. N.L. Safridah, Studi pengumpulan sampah rumah tangga di Kecamatan Wonokromo, Surabaya Selatan (2015)

12. Warmadewanthi, S. Kurniawati. IOP Conf. Series: Earth and Environmental Science, $106(2018)$

13. Y. Trihadiningrum, S. Wignjosoebroto, N.D. Simatupang, S. Tirawaty, O. Damayanti, Proc. of International Seminar on Environmental Technology and Management Conference 2006 (2006)

14. G. Tchobanoglous, H. Theisen, S.A. Vigil, Integrated solid waste management: Engineering principles and issues. (Mc Graw Hill, New York, 1993) 